\title{
ATTRIBUTABLE INDICATORS FOR MEASURING THE LEVEL OF GREENNESS OF CITIES IN DEVELOPING COUNTRIES: LESSONS FROM GHANA.
}

\section{Owusu-Manu ${ }^{1}$, D., *Debrah ${ }^{2}$, C., Oduro-Ofori ${ }^{3}$, E. Edwards ${ }^{4}$, D.J., and Antwi-Afari ${ }^{5}$, P.}

${ }^{1}$ Associate Professor; Department of Construction Technology and Management, Kwame Nkrumah University of Science and Technology, Kumasi, Ghana.

\section{d.owusumanu@gmail.com}

${ }^{2}$ Teaching and Research Assistant; Department of Construction Technology and Management, Kwame Nkrumah University of Science and Technology, Kumasi, Ghana.

\section{cal.debrah@gmail.com}

${ }^{3}$ Senior Lecturer; Department of Planning, Kwame Nkrumah University of Science and Technology, Kumasi, Ghana. odurooforieric@yahoo.com

${ }^{4}$ Professor; School of Engineering and the Built Environment, Birmingham City University, United Kingdom and Faculty of Engineering and the Built Environment, University of Johannesburg, South Africa

\section{drdavidedwards@aol.com}

${ }^{5}$ PhD. Student; Department of Civil Engineering, The University of Hong Kong, Pokfulam, Hong Kong SAR, China antwi.afari@gmail.com

*Corresponding Author.

\begin{abstract}
Purpose: The advances in green city growth is widely discussed in extant literature. The benefits of green cities to urban development in recent discussions of sustainability and sustainable development is well-documented and cannot be overemphasized. Although a growing study on green building development in developing countries has been advanced in literature, a paucity of studies explores green cities in developing countries. Moreover, evidence of studies focused on green cities development in Ghana is lacking. From the
\end{abstract}


identified knowledge gap, the aim of this study is to establish the indicators/attributes for measuring the level of greenness of cities in developing countries.

Design/Methodology/Approach: A comprehensive literature review was conducted to identify the indicators/attributes for measuring the level of greenness of cities in developing countries. This study adopted the pragmatism as its undergirding research philosophy and the deductive research approach. In terms of methodological choice, quantitative research strategy was used to collect data from experts in sustainable urban development. The primary data retrieved from the study were analysed using Descriptive Statistics, Relative Importance Index, and One-sample t-test. The reliability and validity of the study were measured with the Cronbach's Alpha test.

Findings: The study established 8 indicators for measuring green city development: air quality, water, sanitation, land use, health and safety, transportation, energy as well as building and construction. It was discovered that the development of green cities should enhance air quality, improve water production and supply, improve management in sanitation, promote mixed and integrative land use, maintain the health and safety of city dwellers, reduce the demand for transportation and formalise public transport, adopt renewable and efficient energy technologies and promote sustainable construction and green buildings. These indicators are key to policy making and implementation of green cities development.

Research Limitations/Implications: The study was focused in Ghana but not from other developing countries, however, the findings of this study do not limit the generalisability since the findings of the study can be used as a lesson to other developing countries.

Practical and theoretical implications: Theoretically, this study adopted quantitative indicators that is reproducible in another geographical context. This study contributively adds to the discourse on sustainability especially in Ghana and as a source of reference to motivate others to conduct further research in related areas. The outcomes of this study will help the local government, policy makers, city stakeholders and industry expertise gain insights in the overall indicators that underpin green city development.

Originality/value: This paper attempts to posit in literature the foremost appraisal of green city indicators adaptive in Ghana which could motivate other developing countries to develop their own green cities.

Keywords: Attributes, Ghana, Green Cities, Indicators, Sustainable Cities, Sustainable Development.

Paper type: Research Paper

\section{INTRODUCTION}

Cities are the most dramatic manifestations of human activities on the surface of the earth

(Yigitcanlar and Kamruzzaman, 2019). Over the past decades, cities have been receiving 
enhanced scientific and political attention (Bulkeley, 2010). Growing cities are dense in relation to land use, as well as the challenge accompanying its governance as a result of the diverse social and economic fabric (WEF, 2016). However, Larbi (2019) averred that cities are the epicentre of a wide range of global challenges. Cities affect the lion's share of global and local environmental challenges (Hoornweg and Freire, 2013). Cities make a significant contribution to global issues, including climate change and depletion of biodiversity (Hoornweg and Freire, 2013).

Cities have been addressing different focal dimensions and problems in the interpretation and implementation of sustainability strategies and programs (Broto and Bulkeley, 2013). Frischenbruder and Pellegrino (2006) asserted that as part of designing, planning and developing cities, the progress in the adoption of urban ecological resources for climate change adaptation and mitigation have taken a significant lead. A large number of case studies about cities that manifold sustainability and climate initiatives show that cities can solve societal problems (Bulkeley, 2010).

According to the UN (2014), the Sustainable Development Goals (SDGs) embrace the concept of making cities sustainable for both the current and future generations through the exploration of environmentally friendly, economically taut and socially equitable alternatives to development. The complexities of cities, coupled with the enormous availability of data and the pressure to achieve more with little creates a challenging environment within the context of green city development (Lewis, 2015). Rosenzweig et al. (2018) opined that cities and their citizens already have begun to experience the impact of climate change and a comprehension and prediction of these changes will enable cities to be in preparedness for a more sustainable future hence, green cities. 
The Global Platform for Sustainable Cities, World Bank (2018) viewed that urban growth and climate change creates an imperative and offer opportunities to create green cities to allay such challenges. Cities are recognised as key actors in efforts to alleviate the impacts of climate change (Hoornweg et al., 2011). Several authors agree that the global efforts towards sustainability will be either lost or won in cities (Hoornweg et al., 2011; UN, 2014; Brilhante and Klass, 2018).

The term "green" subscribes to different meanings across the world. The term "green" currently used as a brand in the sustainability discourse (Brilhante and Klass, 2018). In an extant study, Swanwick et al. (2003) stated that green urbanism is an important conception for sustainable development. To make urban areas green demand the need to address the research and knowledge gaps, increase stakeholder participation and promote behavioral or psychological change at the individual, corporate, local and public levels (Hoornweg and Freire, 2013). Green cities have advanced in narratives synonymous with the smart city concept in growing literature (European Commission, 2010). Green cities are critical to sustainable development, given their status as engines of economic growth, centres of population growth and resource consumption and receptacles of culture and innovation (Hoornweg and Freire, 2013). Estevez et al. (2016) agree that green city inhabitants have higher levels of productivity, have lesser energy footprint, consume less resources, demand less roads and communication infrastructure.

Lehmann (2010) described green urbanism as a nexus between environmental, economic, social, political and physical objectives in urban development. Green urbanism allows a collaboration and integrative approach to urban planning and development that permits civil society groups, urban planners, sociologists, policy makers, urban researchers, ecologists, governments and all relevant stakeholders to work interactively towards building sustainable cities (Beatley, 2012). Hammer et al. (2011) stressed that from Paris to Yokohama, Jarkarta 
to Copenhagen, Singapore to Toronto, and Rabat to Dar es Salam, mayors at the urban roundtable were in an agreement that the well-being of cities is intimately tied to enhancing environmental and social inclusion through economically stimulating activities and a focal point to promote green growth.

The advances in green city growth is widely discussed in extant literature. The benefits of green cities to urban development in recent discussions of sustainability and sustainable development is interspersed and cannot be overemphasized. Green city development presents a great opportunity for urban or city development for developing countries to meet the rising demand in rural-urban migration. Population growth and resource depletion call for a more sustainable approach to urban development. Although a growing study on green building development in developing countries has been advanced in literature (Darko et al., 2018; Anzagira et al., 2019; Agyekum et al., 2020), a paucity of studies explores green cities in developing countries. Moreover, it is evident that studies focused on green cities development in Ghana is lacking. From the identified knowledge gap, the aim of this study is to establish the indicators/attributes for measuring the level of greenness of cities in developing countries. Concomitantly, the objectives of this study align with the global aim of achieving sustainable development through urban development. The findings of this study would be beneficial to policy making and academia as a reference point for measuring the level of greenness of cities in Ghana and other developing countries.

\section{THE NEXUS BETWEEN SUSTAINABILITY AND SUSTAINABLE DEVELOPMENT}

The term sustainability has become popular in policy-oriented research as an expression of what policies ought to achieve. The concept of sustainability emerged in response to the weaknesses that resulted from poor resource management, and has been accepted universally (McKenzie, 2004). According to the Brundtland Report, sustainability is meeting the needs of 
the present without compromising the ability of the future generation to meet their own needs (WCED, 1987). Sustainability can also be referred to as the maintenance of well-being over a long, probably an indefinite period (European Commission, 2005). Carter and Easton (2011) agreed that research into the field of sustainability has increased considerably in the last decade. There is an increase in education and awareness relating to energy consumption and their prices, the knowledge of the science behind climate change, and the business effect of environmental and social sustainability. Sustainability is a normative concept that indicates the way humans should react towards nature, and the way they should be responsible towards the current and future generations (Baumgärtner and Quaas, 2010). According to Mosly (2015), significant efforts have been made to promote sustainability in property development as a result of the vast quantity of natural resources being consumed daily globally over decades.

Sustainable development as defined by the Office of the Deputy Prime Minister (ODPM) is the achievement of a better quality of life through the efficient use of resources, which realises continued social progress whilst maintaining stable economic growth and caring for the environment (Office of Government, 2007). Sustainable development implies the incorporation of environmental protection and socio-economic growth (Goldsmith and Crawford, 2014). Oyebanji et al. (2017) asserted that sustainable development encompasses two concepts: the concept of needs (ensuring that essential needs of the poor are adequately met) and the need for addressing every limitation arising from the use of technology and activities of social elements affecting the environment's ability to meet the present and future needs. According to Stoddart (2011), the overarching goal of sustainable development is the long-term stability of the economy and the environment which is only attainable through the incorporation and acceptance of economic, environmental and social issues throughout policy implementation and decision making. 


\section{THE INDUCTIVE REVIEW OF GREEN CITIES}

Taking motivation from WCED (1987), sustainable/green cities are developed in a way that meets the needs of the future without compromising the ability of future generation to meet their own needs. Green means different things to different people (Lewis, 2015; Brilhante and Klaas, 2018). There is no universally accepted definition or solution of a green city applicable to all cities in any country. Singh (2018) refers to the term "green" as environmentallyfriendly practice from building design to landscaping choices. Lewis (2015) however asserted that the term "green" in relation to urban development processes does not address only environmental issues but incorporates social and economic considerations as well. According to Brilhante and Klaas (2018), "green" as a sustainability, eco-friendliness or greening brand is largely used by private and public organisations. A green city is designed for environment and ecological purposes, populated by people who are committed to reducing necessary water and electricity inputs, reducing water and air pollutants and reducing the generation of waste (GGGI, 2015). A green city is therefore responsible for political and social actions and contributes to human wellbeing in order to achieve a high environmental quality (Pace et al., 2016). In terms of complexities green cities cover sustainable development, sustainable communities, sustainable urban areas, bioregionalism, eco-cities, economic development, adequate technology, social ecology, green movement, green towns and communities.

Green cities have the basic components for enhancing the lives of millions of people (Brilhante and Klaas, 2018). Green areas can be buffered by the renovation in and around cities. Green zones provide people with a variety of health and climate advantages, as well as exercise, relaxation and, in some cases, food production areas. Green transport interventions also help to reduce cities' carbon footprint (UNESCO, 2016). Environmental related issues are more pronounced in green city definitions, concepts and methods (EBRD, 2016). According to Lewis (2015), the green city development encapsulates a 3E approach: 
environment (the Green City), equity (the inclusive city) and economy (the competitive city). Mersal (2017) added another dimension of a green city to be a city high in income. Beatley (2012) posited that green cities advances knowledge in the development of cities that acknowledge their interactions with nature by striving to essentially lessen their ecological footprint and take into cognisance their ecological limitations. According to Lehmann (2010), green urbanism models zero emission and zero waste urban design that enhances a compact energy resilient urban development through the transformation and reengineering of existing cities to make them socially responsible and environmentally friendly.

\section{ATTRIBUTES/INDICATORS OF GREEN CITIES DEVELOPMENT}

Brilhante and Klaas (2018) posited that the promotion of extensive use of greenery is about bringing back nature to cities through the balance of green and built spaces: urban green spaces, parks, green roofs, green facades, green linear corridors among others. Pace et al. (2016) asserted that extant studies have provided some evidence of measuring the greenness of cities through the use of rankings, indices and indicators (qualitative or quantitative). Brilhante and Klaas (2018) classed the indicators for measuring green city performance into 8 major thematic areas: Socio-economic (SE), Energy (E), Green space and land use (G), Transport (T), Waste (W), Water (WA), Sanitation (S) and Air quality (A). Pace et al. (2016) agree that the indicator for measuring the greenness of cities cover energy, transport, water, waste, air quality among others.

It is evident in Brilhante and Klaas (2018) that the indicators for measuring green city development or performance are further sub-categorised: SE (Total population, Annual Population growth per year, Gross Domestic Product (GDP) per head, Life Expectancy, Information Communication Technology (ICT) total internet penetration, and Total unemployment rate); E (Electricity consumption per capita, Renewable electricity consumed by the city and $\mathrm{CO}_{2}$ emissions); $\mathrm{G}$ (Green spaces per capita, Population living in slums and 
Population density); T (Length of mass transport network, Modal share of Private and motorised transport, and length of cycling lanes); W (Share of solid waste collected by the city, and Share of solid waste recycled); WA (Water consumption per capita, Unaccounted for water loss, and Access to potable water); $\mathrm{S}$ (Population with access to improved sanitation, and Share of waste water treated) and A (Daily suspended particulate matter levels).

Energy is directly or indirectly linked to climate change, transport, economic development, public services, health, infrastructure, ICT, density, environmental quality, water, food, and land use (UN-Habitat, 2015). Several authors agree that greening improves health, values, helps to alleviate greenhouse gas emissions, adaptation to climate management, reduction of environmental pollution, city attractiveness, promotes a local micro climate, enhances the reduction of floods in the cities, reduction of heat islands (UN-Habitat, 2015; Brilhante and Klaas, 2018).

Berrini and Bono (2007) reported on the Urban Ecosystem Europe (UEE), a system that offers local government a voluntary assessment of their urban environmental quality. UEE has been endorsed by several city networks, such as Local Governments for Sustainability (ICLEI) Climate Alliance and Union of the Baltic Cities due to the thematic strategy on urban environment the framework employs. UEE was initially employed in 2006 to analyse 26 European cities and 13 European countries. In 2007, the analysis was repeated for 32 cities and 16 countries in Europe including cities in Great Britain Germany, Finland, Denmark, Italy, France, Belgium, Sweden, and Spain (list not exhaustive). The UEE was based on 25 indicators in six main themes: (1) Local Action for Health and Natural common goods (Air quality, Nosie map and noise reduction plan, domestic water consumption, inhabitants served by water treatment plants); (2) Responsible consumption and lifestyle choices (electric consumption variation, amount of principal waste produced, municipal waste processed 
according to differentiated refuse collection schemes, green public procurement procedures and purchasing); (3) Planning, design and better mobility/less traffic (passengers travelling on public transport within the urban area, underground and tram lines in the urban area, number of registered cars, cycle paths and lanes availability, public green areas availability); (4) Local to global: Energy and climate change (setting of an energy balance and a $\mathrm{CO}_{2}$ reduction target, solar power generation in public buildings, inhabitants connected to a district heating system, climate and energy saving policies); (5) Vibrant, sustainable local economy and social equity, justice and cohesion (Demographic and old age dependency (health and safety), female employment (equity), population qualified at highest level of education); (6) Local management towards sustainability and governance (EMAS and ISO 14001 certification of public authorities, level of implementation of agenda 21 processes, electorate voting in city elections, city representatives who are women (equity)).

The European Green City Index (EGCI) 2009 proposed by the EIU (2009) is an adopted indicator for measuring green cities. The Green City Index was assessed on 30 leading European cities belonging 30 European countries using 30 individual indicators of 8 categories: $\mathrm{CO}_{2}$, energy, buildings, transport, water, waste and land use, air quality, environmental governance. The EGCI was based on independent research using available sources like national statistical offices and local governments. The EGCI comprises 17 quantitative indicators and 13 qualitative indicators. The European Green Capital Award (EGCA) has been operational since 2010. The EGCA was adopted by 15 European cities to encourage cities to improve the quality of life through the emphasis of environmental responsibility in urban planning (European Commission, 2010; Joas et al., 2014). The EGCA has 12 indicators under three objectives: greenest city (the relative environmental performance of cities); implementation of efficient and innovative measures; and communication and networking (cities that have robust communication strategy and program) 
(European Commission, 2010). The 12 indicators of EGCA are: climate change (mitigation and adaptation); local transport; green urban areas incorporating land use; nature and biodiversity; ambient air quality; quality of the acoustic environment; waste production and management; waste water management; eco-innovation and sustainable employment; energy performance and integrated environmental management. The SDG 11 promotes the development of cities and human settlements that are safe, resilient and sustainable. 13 categories of indicators play an evaluative role in measuring the greenness of cities under SDG 11: $\mathrm{CO}_{2}$, air quality; energy, buildings, transport, water, waste, green areas and land use, acoustic environment, health and safety. Education, equity and participation (Pace et al., 2016).

\section{RESEARCH METHODS}

The pragmatist approach underpinned the development of this study. According to Elkjaer and Simpson (2011), for a pragmatist, research starts with a problem, and aims to contribute practical solutions that inform future practice. The overarching method stipulated for this study was quantitative research strategy. Borkan (2004) stressed that quantitative data collection techniques allow the researcher to infer only about that which is being examined and that the statistical technique may work best in isolating or identifying the correlates associated with variations at different points in time. This research adopted the deductive approach in agreement with Zikmund (2000) who emphasised that deductive methodology tests existing theory in an empirical setting. After a comprehensive literature review, data was then collected from participants. This is consistent with Nakano and Muniz Jr. (2018) who agreed that literature review plays the fundamental role in underpinning the concepts of a study. This study adopted a survey research design through the use of questionnaires. Surveys are a very traditional way of conducting research. They are particularly useful for non- 
experimental descriptive designs that seek to describe reality (Mathers et al., 2007). A desk survey preceded the field survey through the use of questionnaires to solicit primary data. The questionnaire included two sections which contributed to achieving the main aim of the study. The first section focused on obtaining the bio-data of the respondents and the second part was fixated on establishing the attributes/indicators for measuring the level of greenness of cities in developing countries. In this study, a structured survey questionnaire was selfadministered (through a combination of an online survey and the drop-and-pick method) to achieve a $77 \%$ response rate. This is consistent with Dillman et al. (2014), Owusu-Manu et al. (2019) and Kissi et al. (2020) who adopted this approach and respectively achieved a response rate of $57 \%$ and $75 \%$ correspondingly.

Due to the challenges encountered in evaluating the population size, the study adopted the non-probability sampling techniques (purposive and snowballing sampling techniques) adopted in Creswell and Creswell (2017) and Owusu-Manu et al. (2019) in the determination of the sample size. Purposive sampling enables the use of judgement to choose people that are present or are available and best meet the objectives of the study (Neville, 2007). Based on these, the criteria for selecting respondents for this study were as follows in agreement with Kissi et al. (2020): the respondent must have had at least earned a bachelor's degree, relevant to the field of study; the respondent should have had a minimum of two years' relevant working experience and must have at least been involved in the city development. The respondent must have demonstrated good knowledge in the area of research. Work experience has been perceived to guarantee the quality and quantity in the performance of a specific task. Snowball sampling assumes relevant respondents are connected so that we can use those connections to construct a sample from a small initial sample (Noy, 2008). According to Bernard (2017), in using a purposive sample, there is no cap on how many respondents is adequate for the study. A sample is adequate when the all 
information needed for the study has been obtained. This included 200 experts in green cities development (i.e. Surveyors, Construction Managers, Architects, Sustainability Lecturers, Project Managers, Engineers, Energy experts, Security Analysts and experts, Health and Safety Officers, Finance experts, Development practitioners, Environmental Officers, Urban and Development Planners, District/Municipal/Metropolitan Directors). The sample for this study included only agencies of the state and professionals who have lines of influence on the greening of our cities and sustainable urban development.

The primary data retrieved from the study were analysed using Descriptive Statistics tools such as Means and Standard Deviations. Other tools such as Relative Important Index (RII) and the One-sample t-test were also used. According to Rooshdi et al. (2018), RII allows the identification of the most important criteria based on the responses of the participants of the survey and it is also an appropriate tool to prioritise the indicators rated on the Likert scale adopted for the study. The RII was calculated using the formula below: [W - weighting given to each statement by the respondents ranging from 1 to 5; $A$ - higher response integer (5); $N$ - total number of respondents].

$$
\begin{array}{r}
\mathrm{RII}=\sum w \\
\mathrm{~A} * \mathrm{~N}
\end{array}
$$

One Sample T-test is a statistical procedure used to examine the mean difference between the sample and the known value of the population mean. The one sample T-test is used to establish the relative significance of the variables (Ahadzie, 2007; Owusu-Manu et al., 2018). The Cronbach's Alpha Coefficient test was used to ascertain the reliability and internal consistency of the scale adopted for the study. Tavakol and Dennick (2011) stressed that a scale is considered reliable if the Cronbach Alpha test results in a co-efficient of 0.700 or greater. An overall Cronbach's Alpha of 0.916 for the study depicted its reliability for further analysis. The validity of the questionnaire was tested through a pilot study (Mathers et al., 
2007) that involved 9 respondents out of 10 sampled experts in green cities development. The comments and observations from the pilot study were adopted to ascertaining the content validity of the data collection instrument for a larger target population in agreement with Polit and Beck (2004). The Statistical Package for Social Sciences (SPSS) windows version 23 aided the analysis.

\section{DEMOGRAPHIC PROFILE OF RESPONDENTS}

This section was targeted to validate the responses elicited for the study. Knowledge of the background of respondents puts confidence in data gathered on a research work and makes the responses more credible (Pandey and Pandey, 2015).

Table 1. Demographic Profile

\begin{tabular}{lll} 
Area of Expertise & Frequency & Percent \\
\hline \hline Business and Finance & 14 & 9.1 \\
\hline Governance & 16 & 10.4 \\
\hline Infrastructure and Planning & 52 & 33.8 \\
\hline Health and Safety & 9 & 5.8 \\
\hline Environment, Water and Sanitation & 19 & 12.3 \\
\hline Education & 27 & 17.5 \\
\hline Energy and Security & 17 & 11.0 \\
\hline Years of Experience & & \\
\hline \hline 1-5 years & 71 & 46.1 \\
\hline $6-10$ years & 50 & 32.5 \\
\hline 11-15 years & 20 & 13.0 \\
\hline 16-20 years & 13 & 8.4 \\
\hline Academic Qualification & & \\
\hline \hline Bachelor's Degree (BSs/BA/BEd) & 84 & 54.5 \\
\hline Master's Degree (MSc/MPhil/MA/MBA) & 56 & 36.4 \\
\hline Doctoral Degree (PhD/DBA) & 14 & 9.1 \\
\hline \hline Familiarity with the green city concept & & \\
\hline Not at all & 2 & 1.3 \\
\hline Somewhat & 18 & 46.8 \\
\hline Familiar & 72 & 31.8 \\
\hline Very Familiar & 49 & 8.4 \\
\hline Expert & 13 & $\mathbf{1 0 0 . 0}$ \\
\hline \hline Total & $\mathbf{1 5 4}$ & \\
\hline \hline
\end{tabular}


Source: Field Survey (2020)

$75 \%$ of the respondents viewed that Kumasi city (Ghana) has the proclivity of becoming green with its characteristic nature of multidimensionality; high environmental performance; human wellbeing and responsible society and being ranked among the current green cities like London, New York, Delhi, Lagos, Mexico City, Berlin, Johannesburg, Shanghai and Buenos Aires (Brilhante and Klass, 2018). It is evident that majority of the respondents have experience between the years of 1-5 years. According to Leksakundilok (2004) a varied experience is to ensure that they can be the representation of what represents the community or city. It evident that majority of the respondent were Infrastructure and Planning experts (33.8\%), closely followed by Educationist - Sustainability related (17.5\%). The varied level of respondent expertise adopted for this study is consistent with Hammer et al. (2011) who asserted that green city development should be assessed from technical, stakeholder and political perspectives. $54.5 \%$ of the representing the majority had attained at least a Bachelor's Degree or higher. Table 1 shows the bio-data of the respondents for the study. Furthermore, in agreement with Hegarty (2011), academic qualification can help to gain more knowledge for professional development and organisational development.

\section{REQUIREMENTS OF A GREEN CITY}

Respondents were asked to determine the level of agreement of a paradigm shift towards environmental responsibility, economic sustainability and social prosperity towards the development of a green city. As shown in Fig. 1, majority of the respondents agreed to the need for a paradigm shift in green city development. In agreement with (Loures (2019), it is apparent that green cities demand a paradigm shift (i.e. environment is essential to economic sustainability and social prosperity) in land-use planning, policy making, and community engagement. 


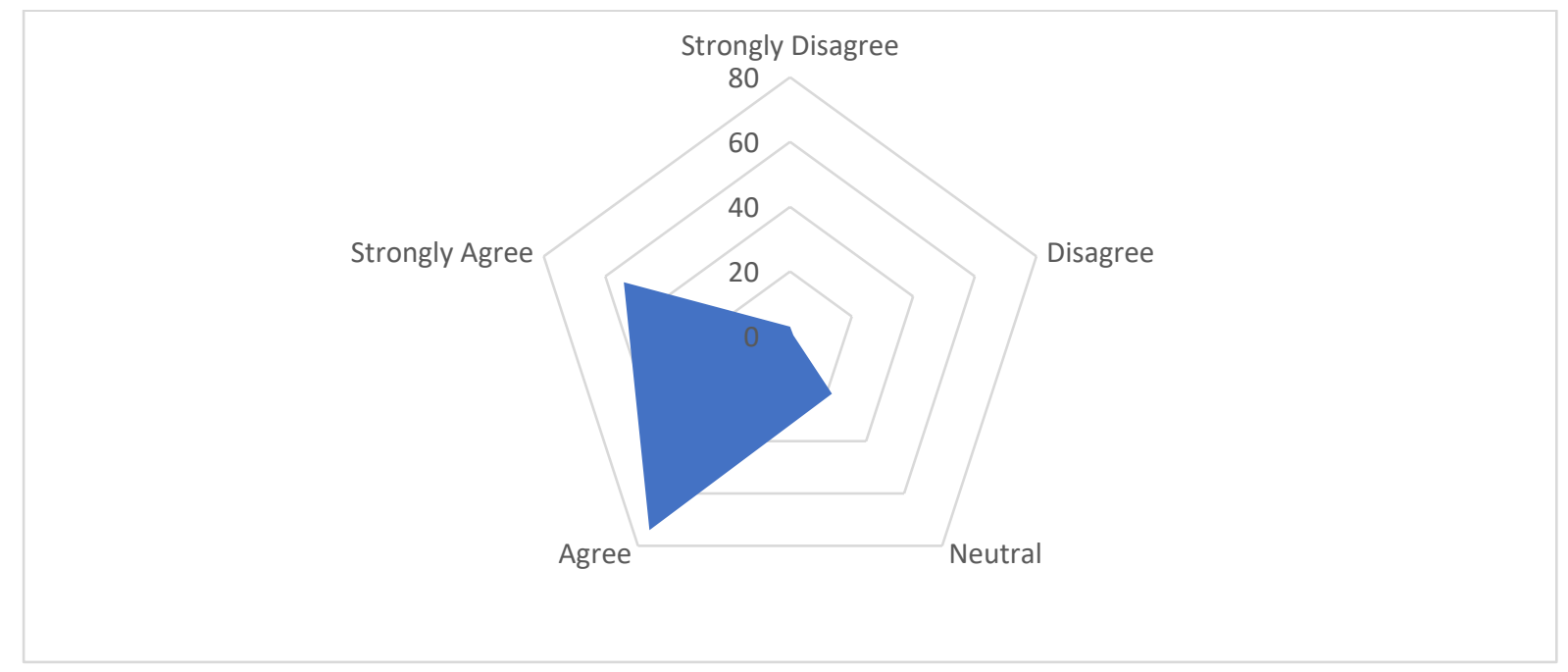

Fig. 1 Radar Diagram Indicating the Level of Agreement to a Paradigm Shift towards the pillars of Sustainability.

\section{DESCRIPTIVE STATISTICS}

Descriptive statistics enable a researcher to reduce, summarise and describe quantitative data obtained from empirical evidence (Polit and Beck, 2004). In an effort to realise the indicators/attributes for measuring the level of greenness of cities in developing countries, the study adopted indicators that has been used in the measurement of the greenness of cities from the literature review. Respondents were asked to rank on a 5-point Likert scale the indicators for measuring the level of greenness of cities in developing countries [1-Strongly Disagree; 2-Disagree; 3-Neutral; 4-Agree; 5-Strongly Agree]. The Mean Score Rank and the Relative Importance Index (RII) were used to analyse the responses from the field survey. As part of the Mean Score Rank, the standard deviation (SD) was determined to ascertain the level of agreement of the responses given. The SD is a measure of variability (Altman and Bland, 2005). The Standard error (SE) estimates how sample means vary or deviates from the SD of the sampling distribution. According to Rooshdi et al. (2018), RII allows the identification of the most important criteria based on the responses of the participants of the survey. It is also an appropriate tool to prioritise the indicators rated on the Likert scale 
adopted for the study. Also, the normality of the data was checked by using univariate skewness and kurtosis in the analysis. Kline (2015) iterated that the normality of data could be confirmed by using univariate skewness and kurtosis if the absolute value of the skewness and kurtosis is less than 3.0 and 8.0 respectively. Inspecting Table 2 confirms that the study had a good normality of data. Hence, all the skewness and kurtosis had an absolute value less than 3.0 and 8.0 respectively. Where two or more variables have the same RII, the variable with the highest mean is ranked higher. Moreover, where two or more variables have the same mean, the one with the lowest standard deviation is given the precedence in terms of ranking. This is because the SD measures the consistency of agreement between the respondents' interpretation, and hence, the lower the standard deviation number the better (Altman and Bland, 2005; Ahadzie, 2007; Owusu-Manu et al., 2019).

In using the hypothesised mean of 3.5 as adopted by Owusu-Manu et al. (2018). It was obvious from Table 2 that all the indicators had means greater than the hypothesised mean of 3.5 and their standard error means were also close to zero indicating a great consistency among the agreement between the respondents. This is consistent with Owusu-Manu et al. (2019) and Altman and Bland (2005). The indicators for measuring green city were categorised into 8 indicators: Air Quality (9 variables), Water (9 variables), Sanitation (8 variables), Land Use (10 variables), Health and Safety (10 variables), Transportation (7 variables), Energy (9 variables) as well as Building and Construction (10 variables). The various indicators were ranked under the categories as well as the overall ranking.

The most important indicator as agreed by respondents was "Water" with an RII of 0.85 , a Mean Score of 4.25 and an SD of 0.831. Under this category "Efficient water storage system" $[\mathrm{RII}=0.88$, Mean=4.40 and $\mathrm{SD}=0.775]$, "Access to improved water for all" $[\mathrm{RII}=0.88$, Mean=4.40 and SD=0.787], and "Improved sustainability of water treatment" $[\mathrm{RII}=0.88$, 
Mean=4.38 and $\mathrm{SD}=0.826$, were the highest ranked variables ranking first, second and third respectively.

According to the respondents, the second ranked category for measuring Green Cities was "Sanitation" with a RII of 0.85 , a Mean score of 4.24 and an SD of 0.884 . "Improving the collecting of waste" $[\mathrm{RII}=0.88$, Mean=4.38 and $\mathrm{SD}=0.864]$, "Minimal waste production or generation" $[\mathrm{RII}=0.88$, Mean $=4.38$ and $\mathrm{SD}=0.930]$, and "Maximising the variation of the waste through composting" [RII $=0.88, M e a n=4.38$ and $\mathrm{SD}=0.930]$ were the leading indicators under Sanitation as ranked by the respondents correspondingly.

"Energy" ranked as the third most significant Green City Indicator category with an RII of 0.84, a Mean Score of 4.18 and an SD of 0.894. "Promoting energy efficient technologies in the city" $[\mathrm{RII}=0.86, \mathrm{Mean}=4.29$ and $\mathrm{SD}=0.781]$, "Promoting renewable energy in the city" $[\mathrm{RII}=0.86$, Mean=4.29 and SD=0.927], "Energy saving policies" [RII=0.85, Mean=4.26 and $\mathrm{SD}=0.913$ ] ranked first, second and third respectively as the most significant variables under the Energy indicator.

The fourth ranked category of Green City Indicator was "Land Use" according to the respondents for the survey. This recorded an RII of 0.85, a Mean Score of 4.19 and an SD of 0.913. "Many green parks" [RII=0.86, Mean=4.32 and $\mathrm{SD}=0.853]$, "Preserving ecosystem and biodiversity" $[\mathrm{RII}=0.86$, Mean $=4.31$ and $\mathrm{SD}=0.835]$, and "Urban green spaces" $[\mathrm{RII}=0.86$, Mean=4.29 and $\mathrm{SD}=0.855]$ ranked as the top three variables under Land Use as an indicator for measuring Green City development.

"Building and Construction" was the fifth ranked indicator for measuring Green City development according to the responses from the survey with an RII of 0.82 , a mean score of 4.11 and an SD of 0.842. The top three variables under this Green City Indicator were "Use of renewable resources" [RII=0.86, Mean=4.29 and $\mathrm{SD}=0.822]$, "Efficient design" [RII=0.85, 
Mean=4.26 and $\mathrm{SD}=0.799]$, and "Natural ventilation" [RII=0.85, Mean=4.295 and $\mathrm{SD}=0.821]$ correspondingly. 
Table 1. One Sample T-test of Indicators of Green Cities in Developing Countries

\begin{tabular}{|c|c|c|c|c|c|c|c|c|}
\hline Indicators of a Green City & Mean & $\begin{array}{c}\text { Std. } \\
\text { Deviation }\end{array}$ & RII & Rank & $\begin{array}{c}\text { Overall } \\
\text { Rank }\end{array}$ & $\begin{array}{c}\text { t-value } \\
(3.5)\end{array}$ & p-value & $\begin{array}{c}\text { Null } \\
\text { Hypothesis }\end{array}$ \\
\hline Air Quality & 4.01 & 0.927 & $\mathbf{0 . 8 0}$ & & \multirow{10}{*}{$7^{\text {th }}$} & & & \\
\hline Ambient air quality & 4.16 & 0.874 & 0.83 & $\overline{1^{\text {st }}}$ & & 9.402 & 0.000 & Not rejected \\
\hline Clean air policies & 4.15 & 0.899 & 0.83 & $2^{\text {nd }}$ & & 8.967 & 0.000 & Not rejected \\
\hline Reduction of greenhouse gases & 4.14 & 0.932 & 0.83 & $3^{\text {rd }}$ & & 8.561 & 0.000 & Not rejected \\
\hline $\mathrm{CO} 2$ reduction target & 4.12 & 0.895 & 0.82 & $4^{\text {th }}$ & & 8.640 & 0.000 & Not rejected \\
\hline Air emission rules & 4.05 & 0.931 & 0.81 & $5^{\text {th }}$ & & 7.269 & 0.000 & Not rejected \\
\hline Reduction of Sulphur and Nitrogen dioxide & 3.94 & 0.919 & 0.79 & $6^{\text {th }}$ & & 5.872 & 0.000 & Not rejected \\
\hline Negligible air pollution and monitoring & 3.86 & 1.067 & 0.77 & $7^{\text {th }}$ & & 4.230 & 0.000 & Not rejected \\
\hline Low concentration of Particulate matter $(\mathrm{PM})$ in the air & 3.86 & 0.851 & 0.77 & $8^{\text {th }}$ & & 5.207 & 0.000 & Not rejected \\
\hline Reduced air temperature & 3.81 & 0.971 & 0.76 & $9^{\text {th }}$ & & 3.902 & 0.000 & Not rejected \\
\hline Water & 4.25 & 0.831 & $\overline{0.85}$ & & \multirow{9}{*}{$\mathbf{1}^{\text {st }}$} & & & \\
\hline  & 4.40 & 0.755 & 0.88 & $\mathbf{1}^{\mathrm{st}}$ & & 12.478 & 0.000 & Not rejected \\
\hline Access to improved water for all & 4.40 & 0.787 & 0.88 & $2^{\text {nd }}$ & & 14.125 & 0.000 & Not rejected \\
\hline Improved sustainability of water treatment & 4.38 & 0.826 & 0.88 & $3^{\text {rd }}$ & & 13.267 & 0.000 & Not rejected \\
\hline Preserving water sources & 4.38 & 0.871 & 0.88 & $4^{\text {th }}$ & & 12.485 & 0.000 & Not rejected \\
\hline Optimisation of the consumption of clean water & 4.29 & 0.816 & 0.86 & $5^{\text {th }}$ & & 12.049 & 0.000 & Not rejected \\
\hline efficient water distribution system & 4.22 & 0.850 & 0.84 & $6^{\text {th }}$ & & 10.525 & 0.000 & Not rejected \\
\hline Treatment and reuse or disposal of sludge & 4.19 & 0.825 & 0.84 & $7^{\text {th }}$ & & 10.450 & 0.000 & Not rejected \\
\hline Domestic water consumption & 4.05 & 0.843 & 0.81 & $8^{\text {th }}$ & & 8.031 & 0.000 & Not rejected \\
\hline
\end{tabular}




\begin{tabular}{|c|c|c|c|c|c|c|c|c|}
\hline Sanitation & 4.24 & 0.884 & $\mathbf{0 . 8 5}$ & & \multirow{9}{*}{$2^{\text {nd }}$} & & & \\
\hline Improving the collecting of waste & 4.38 & 0.864 & 0.88 & $1^{\text {st }}$ & & 10.968 & 0.000 & Not rejected \\
\hline Minimal waste production generation & 4.38 & 0.930 & 0.88 & $2^{\text {nd }}$ & & 9.997 & 0.000 & Not rejected \\
\hline Maximising the variation of the waste through composting & 4.32 & 0.885 & 0.86 & $3^{\text {rd }}$ & & 8.903 & 0.000 & Not rejected \\
\hline Differentiated refuse collection schemes & 4.22 & 0.895 & 0.84 & $4^{\text {th }}$ & & 9.483 & 0.000 & Not rejected \\
\hline Waste management plan & 4.16 & 0.864 & 0.83 & $5^{\text {th }}$ & & 11.567 & 0.000 & Not rejected \\
\hline Designing of green and efficient sanitary landfills & 4.16 & 0.867 & 0.83 & $6^{\text {th }}$ & & 9.418 & 0.000 & Not rejected \\
\hline Reducing flooding in cities & 4.16 & 0.868 & 0.83 & $7^{\text {th }}$ & & 11.781 & 0.000 & Not rejected \\
\hline Recycling and reusing & 4.14 & 0.896 & 0.83 & $8^{\text {th }}$ & & 12.594 & 0.000 & Not rejected \\
\hline Land use & 4.19 & 0.913 & 0.84 & & \multirow{11}{*}{$4^{\text {th }}$} & & & \\
\hline Many green parks & 4.32 & 0.853 & 0.86 & $1^{\text {st }}$ & & 11.498 & 0.000 & Not rejected \\
\hline Preserving ecosystem and biodiversity & 4.31 & 0.835 & 0.86 & $2^{\text {nd }}$ & & 11.899 & 0.000 & Not rejected \\
\hline Urban green spaces & 4.29 & 0.855 & 0.86 & $3^{\text {rd }}$ & & 11.968 & 0.000 & Not rejected \\
\hline Promoting outdoor living and green spaces & 4.28 & 0.804 & 0.86 & $4^{\text {th }}$ & & 12.022 & 0.000 & Not rejected \\
\hline City attractiveness & 4.25 & 0.926 & 0.85 & $5^{\text {th }}$ & & 10.097 & 0.000 & Not rejected \\
\hline Tourism centre in the city & 4.15 & 1.053 & 0.83 & $6^{\text {th }}$ & & 7.655 & 0.000 & Not rejected \\
\hline Preserving cultural heritage & 4.14 & 0.925 & 0.83 & $7^{\text {th }}$ & & 8.626 & 0.000 & Not rejected \\
\hline Efficient and pedestrian-friendly streets & 4.13 & 0.891 & 0.83 & $8^{\text {th }}$ & & 8.775 & 0.000 & Not rejected \\
\hline Zero-waste (avoid, reduce, recycle or recover) & 4.13 & 1.052 & 0.83 & $9^{\text {th }}$ & & 7.428 & 0.000 & Not rejected \\
\hline Promoting mixed land use & 3.88 & 0.935 & 0.78 & $10^{\text {th }}$ & & 5.082 & 0.000 & Not rejected \\
\hline
\end{tabular}




\begin{tabular}{|c|c|c|c|c|c|c|c|c|}
\hline Health and Safety & 4.08 & 0.903 & 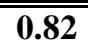 & & \multirow{11}{*}{$6^{\text {th }}$} & & & \\
\hline Health and wellbeing of the citizens & 4.31 & 0.744 & 0.86 & $\mathbf{1}^{\text {st }}$ & & 13.433 & 0.000 & Not rejected \\
\hline Proper health system & 4.18 & 0.896 & 0.84 & $2^{\text {nd }}$ & & 9.440 & 0.000 & Not rejected \\
\hline Adaption of climate management & 4.14 & 0.784 & 0.83 & $3^{\text {rd }}$ & & 10.068 & 0.000 & Not rejected \\
\hline Reduction of physical and chemical hazards & 4.14 & 0.812 & 0.83 & $4^{\text {th }}$ & & 9.826 & 0.000 & Not rejected \\
\hline Resilience in the face of natural disasters & 4.08 & 0.855 & 0.82 & $5^{\text {th }}$ & & 8.480 & 0.000 & Not rejected \\
\hline Controlling disease and their health burden & 4.08 & 0.926 & 0.82 & $6^{\text {th }}$ & & 7.749 & 0.000 & Not rejected \\
\hline Easy and affordable access to health & 4.06 & 1.077 & 0.81 & $7^{\text {th }}$ & & 6.512 & 0.000 & Not rejected \\
\hline National health policy & 4.05 & 0.895 & 0.81 & $8^{\text {th }}$ & & 7.559 & 0.000 & Not rejected \\
\hline Low rate of infection in major disease outbreak & 3.98 & 1.006 & 0.80 & $9^{\text {th }}$ & & 5.926 & 0.000 & Not rejected \\
\hline Zero hunger & 3.80 & 1.038 & 0.76 & $10^{\text {th }}$ & & 3.572 & 0.000 & Not rejected \\
\hline Transportation & 3.93 & 0.965 & 0.79 & & \multirow{8}{*}{$\mathbf{8}^{\text {th }}$} & & & \\
\hline Parking management & 4.12 & 0.992 & 0.82 & $\mathbf{1}^{\text {st }}$ & & 7.796 & 0.000 & Not rejected \\
\hline Quality transport system and bicycles lanes & 4.06 & 0.865 & 0.81 & $2^{\text {nd }}$ & & 8.012 & 0.000 & Not rejected \\
\hline Pedestrianization of central business district & 4.05 & 0.895 & 0.81 & $3^{\text {rd }}$ & & 7.559 & 0.000 & Not rejected \\
\hline Formalized public transport & 4.03 & 0.874 & 0.81 & $4^{\text {th }}$ & & 7.562 & 0.000 & Not rejected \\
\hline Full integrative transport planning & 4.00 & 0.936 & 0.80 & $5^{\text {th }}$ & & 6.630 & 0.000 & Not rejected \\
\hline Better mobility /less traffic in the city & 3.94 & 0.941 & 0.79 & $6^{\text {th }}$ & & 5.740 & 0.000 & Not rejected \\
\hline Banning all private motorized vehicles in the inner city & 3.32 & 1.225 & 0.66 & $7^{\text {th }}$ & & 1.843 & 0.966 & Not rejected \\
\hline Energy & 4.18 & 0.894 & 0.84 & & $\mathbf{3}^{\text {rd }}$ & & & \\
\hline
\end{tabular}




\begin{tabular}{|c|c|c|c|c|c|c|c|c|}
\hline Promoting energy efficient technologies in the city & 4.29 & 0.781 & 0.86 & $\mathbf{1}^{\text {st }}$ & & 12.478 & 0.000 & Not rejected \\
\hline Promoting renewable energy in the city & 4.29 & 0.927 & 0.86 & $2^{\text {nd }}$ & & 10.520 & 0.000 & Not rejected \\
\hline Energy saving policies & 4.26 & 0.913 & 0.85 & $3^{\text {rd }}$ & & 10.324 & 0.000 & Not rejected \\
\hline Clean the efficient energy policies & 4.21 & 0.775 & 0.84 & $4^{\text {th }}$ & & 11.435 & 0.000 & Not rejected \\
\hline Reducing energy consumption & 4.21 & 0.824 & 0.84 & $5^{\text {th }}$ & & 11.435 & 0.000 & Not rejected \\
\hline Conversion of Energy-consuming facilities into energy & 4.16 & 0.93 & 0.83 & $6^{\text {th }}$ & & 8.754 & 0.000 & Not rejected \\
\hline Uninterrupted access to power/energy & 4.14 & 0.966 & 0.83 & $7^{\text {th }}$ & & 8.256 & 0.000 & Not rejected \\
\hline Energy consumption by the city & 4.04 & 0.963 & 0.81 & $8^{\text {th }}$ & & 4.948 & 0.000 & Not rejected \\
\hline Biomass and alternatives & 3.98 & 0.967 & 0.80 & $9^{\text {th }}$ & & 6.169 & 0.000 & Not rejected \\
\hline Building and Construction & 4.11 & 0.842 & $\overline{0.82}$ & & & & & \\
\hline Use of renewable resources & 4.29 & 0.822 & 0.86 & $\mathbf{1}^{\text {st }}$ & & 11.859 & 0.000 & Not rejected \\
\hline Efficient design & 4.26 & 0.799 & 0.85 & $2^{\text {nd }}$ & & 11.804 & 0.000 & Not rejected \\
\hline Natural ventilation & 4.25 & 0.821 & 0.85 & $3^{\text {rd }}$ & & 11.386 & 0.000 & Not rejected \\
\hline Natural lighting & 4.14 & 0.787 & 0.83 & $4^{\text {th }}$ & & 10.132 & 0.000 & Not rejected \\
\hline Affordable social housing & 4.14 & 0.881 & 0.83 & $5^{\text {th }}$ & $5^{\text {th }}$ & 9.051 & 0.000 & Not rejected \\
\hline Sun shading & 4.10 & 0.948 & 0.82 & $6^{\text {th }}$ & & 7.819 & 0.000 & Not rejected \\
\hline Green linear corridors & 4.03 & 0.816 & 0.81 & $7^{\text {th }}$ & & 7.998 & 0.000 & Not rejected \\
\hline Green facades & 4.01 & 0.792 & 0.80 & $8^{\text {th }}$ & & 8.038 & 0.000 & Not rejected \\
\hline Green public procurement & 3.99 & 0.812 & 0.80 & $9^{\text {th }}$ & & 7.538 & 0.000 & Not rejected \\
\hline Green/vegetated roofing & 3.99 & 0.907 & 0.80 & $10^{\text {th }}$ & & 6.661 & 0.000 & Not rejected \\
\hline
\end{tabular}


The Sixth ranked category of indicator for measuring Green City development was "Health and Safety" with an RII of 0.82 , a mean score of 4.08 and an SD of 0.903 . "Health and wellbeing of the citizens" $[\mathrm{RII}=0.86$, Mean=4.31 and $\mathrm{SD}=0.744]$, "Proper health system" $[\mathrm{RII}=0.84$, Mean=4.18 and $\mathrm{SD}=0.896]$, and "Adaption of climate management" $[\mathrm{RII}=0.83$, Mean=4.14 and $\mathrm{SD}=0.784]$ ranked as the leading variables respectively under the Health and Safety category.

Recording an RII of 0.80, a mean score of 4.01 and an SD of 0.927 , “Air Quality" ranked as the seventh most important category of indicator for measuring Green City development. "Ambient air quality" $[\mathrm{RII}=0.83$, Mean=4.16 and $\mathrm{SD}=0.927]$, "Clean air policies" $[\mathrm{RII}=0.83$, Mean=4.15 and $\mathrm{SD}=0.899]$, and "Reduction of greenhouse gases" $[\mathrm{RII}=0.83$, Mean=4.14 and $\mathrm{SD}=0.932]$ ranked first, second and third respectively under the Air Quality category.

The least ranked category of indicator for measuring Green City development was "Transportation" with an RII of 0.79, a mean score of 3.93 and an SD of 0.965. "Parking management" $[\mathrm{RII}=0.82$, Mean=4.12 and $\mathrm{SD}=0.992]$, "Quality transport system and bicycles lanes" $[\mathrm{RII}=0.81$, Mean=4.06 and $\mathrm{SD}=0.865]$, and "Pedestrianization of central business district" $[\mathrm{RII}=0.81$, Mean=4.06 and $\mathrm{SD}=0.865]$ ranked first, second and third respectively under the Transportation category as an indicator for measuring Green City development.

\section{ONE-SAMPLE T-TEST}

The One-Sample T-test was done to further ascertain the significance of the indicators for measuring the level of greenness of cities. The one sample T-test is used to establish the relative significance of the variables (Ahadzie, 2007; Ross and Willson, 2017; Owusu-Manu et al., 2018). At a $95 \%$ confidence level with a p-value of less than 0.05 , and a test value of 3.5, the one sample T-test was adopted to further determine the statistical significance of the 
indicators for measuring the level of greenness of cities. The study adopted a hypothesised mean of 3.5 (Uo) for one sample T-test signifying that the factors with mean of 3.5 or above are significant indicators for measuring Green City development. In this study, the null hypothesis (Ho) is that "the mean value is not statistically significant indicator for measuring Green City development" whilst the alternative hypothesis (Ha) means that "the mean value is statistically a significant indicator for measuring Green City development". In agreement with Owusu-Manu et al. (2018), the 95\% confidence level interval estimates the difference between the population mean weight and the test value (3.5). For each variable, the null hypothesis was that the variable was not a significant indicator for measuring Green City development (Ho: U=Uo). According to Owusu-Manu et al. (2018), Uo is the critical rating above which the variable is considered to be important. The p-value is the probability that the random variables takes on values that a farther away from the mean assuming the null hypothesis is true. Impliedly, the null hypothesis would not be rejected once the p-value is less than 0.05 in using one sample T-test (Ross and Willson, 2017). All the factors had tvalues (strength of the test) that were positive indicative that their means were significantly above the hypothesised mean as shown in Table 2. Furthermore, all the indicators for measuring Green City development had a p-value (significance of the test) less than 0.05 implying that the means of these variables are not significantly different from the hypothesised mean of 3.5. Hence the null hypothesis for the study is not rejected and all the variables are significant indicators for measuring Green City development in Ghana (Kumasi).

\section{DISCUSSION OF FINDINGS}

From the analysis of the data, it was evident that all the category of indicators for measuring the Green City development were significant to the study: Air Quality (9 variables), Water (9 
variables), Sanitation (8 variables), Land Use (10 variables), Health and Safety (10 variables), Transportation (7 variables), Energy (9 variables) as well as Building and Construction (10 variables). The various indicators were ranked under the categories as well as the overall ranking.

Ranking first was "Water". Under this category "Efficient water storage system", "Access to improved water for all" and "Improved sustainability of water treatment" were the highest ranked variables ranking under this category of green city indicator. This is consistent with Pace et al. (2016) who asserted that extant studies have provided some evidence of measuring the greenness of cities through the use of rankings, indices and indicators (qualitative or quantitative). Brilhante and Klaas (2018) classed the indicators for measuring green city performance into 8 major thematic areas: socio-economic, energy, green space and land use, transport, waste, water, sanitation and air quality. Pace et al. (2016) agree that the indicator for measuring the greenness of cities cover energy, transport, water, waste, and air quality. This is also consistent with European Green City Index (EGCI) 2009 proposed by the EIU (2009) and further validated by Joas et al. (2014). The findings of this study align with The European Green Capital Award (EGCA) (European Commission, 2010; Joas et al., 2014) and the indicators for measuring the greenness of cities under SDG 11 (Pace et al., 2016).

"Sanitation" ranked as the second most important green city indicator with the variables being high ranked: Improving the collecting of waste, Minimal waste production or generation and Maximising the variation of the waste through composting. "Energy" ranked as the third most significant Green City Indicator category with variables ranking highly under the category: Promoting energy efficient technologies in the city, promoting renewable energy in the city and Energy saving policies. In agreement with extant literature, Brilhante and Klaas (2018) extensively asserted that the promotion of renewable energy and energy efficiency in all activities of the city is very cogent and prudent. Energy is directly or 
indirectly linked to climate change, transport, economic development, public services, health, infrastructure, ICT, density, environmental quality, water, food, and land use (UN-Habitat, 2015).

The fourth ranked category of Green City Indicator was "Land Use" according to the respondents for the survey. Many green parks, preserving ecosystem and biodiversity and Urban green spaces ranked as the top three variables under Land Use as an indicator for measuring Green City development. Brilhante and Klaas (2018) posited that the promotion of extensive use of greenery is about bringing back nature to cities through the balance of green and built spaces: urban green spaces, parks, green roofs, green facades, green linear corridors among others. Several authors agree that greening improves health, helps to alleviate greenhouse gas emissions, adaptation to climate management, reduction of environmental pollution, city attractiveness, promotes a local microclimate, enhances the reduction of floods in the cities, reduction of heat islands (UN-Habitat, 2015). Moreover, UNESCO (2016) agreed that green areas can be buffered by the renovation in and around cities. Green zones provide people with a variety of health and climate advantages, as well as exercise, relaxation and, in some cases, food production areas.

"Building and Construction" was the fifth ranked indicator for measuring Green City development according to the responses from the survey. The top three variables under this Green City Indicator were Use of renewable resources, Efficient design and Natural ventilation respectively. The Sixth ranked category of indicators for measuring Green City development was "Health and Safety". Health and wellbeing of the citizens, Proper health system and Adaption of climate management ranked as the leading variables respectively under the Health and Safety category. "Air Quality" ranked as the seventh most important category of indicators for measuring Green City development. Ambient air quality, Clean air 
policies and Reduction of greenhouse gases ranked first, second and third respectively under the Air Quality category.

The least ranked category of indicators for measuring Green City development was "Transportation". Parking management, Quality transport system and bicycles lanes and Universally accessible footpaths for pedestrians ranked first, second and third respectively under the Transportation category as an indicator for measuring Green City development. Green transport interventions also help to reduce cities' carbon footprint (UNESCO, 2016).

\section{IMPLICATIONS: THEORY, PRACTICE AND POLICY}

This study explored the indicators for measuring the level of greenness of cities in developing countries. In contributing to knowledge, the study is the first to delve deep into the complexities of green cities development in Ghana by revealing the attributable indicators for measuring the level of greenness of cities in developing countries. It was identified after the study that green cities in the light of sustainable development principles must meet the needs of the present generation in terms of air quality, water, sanitation, land use, health and safety, transportation, energy as well as building and construction. Green cities also ensure the ability of posterity to meet their own needs as well. Promotion and implementation of the indicators of green cities identified in this study will encourage resource efficiency and healthy living. This paper attempts to posit in literature the foremost appraisal of green city indicators adaptive in Ghana which could be motivate other developing countries to develop their own green cities. Theoretically, this study adopted quantitative indicators that is reproducible in another geographical context. This study contributively adds to the discourse on sustainability especially in Ghana and as a source of reference to motivate others to conduct further research in related areas. The findings of this study present an opportunity for 
researchers in developing countries to embrace the green city concept in urban sustainable policy development.

The outcomes of this study will help the local government, policy makers, city stakeholders and industry expertise gain insights in the overall indicators that underpin green city development. Practically, this study can aid policy makers, local government, urban developers, and stakeholders in city development as a readily available reference point indicators for measuring the level of greenness of future green cities. The findings under categories (air quality, water, sanitation, land use, health and safety, transportation, energy as well as building and construction) will help direct policy makers and city developer to know the indicators that can be advanced towards the development of green cities in Ghana and other developing countries. This study thus encourages the adoption and implementation of the green city indicators green city development in the Ghanaian context and other developing countries. This can be adopted as a policy guide on sustainable urban development in Ghana and serve as a lesson for other developing countries. There should be constant training and development for all stakeholders in green city development. This would help stakeholders to fully understand and grasp the full benefits of a green city, develop stratagems to fully and locally adapt the attributable indicators of green cities to align with community focus.

\section{CONCLUSION AND RECOMMENDATIONS}

The aim of this study is to establish the indicators/attributes for measuring the level of greenness of cities in developing countries. The concept of green cities should be allcompassing and well-embracing and requires the collaborative efforts of all stakeholders in urban development. The unit of analysis for the study comprised experts in green cities development. Purposive and snowballing sampling techniques was used in selecting the green 
cities experts from agencies of state and the academia as they had the requisite knowledge to respond to the questionnaires administered. The study adopted Cronbach's Alpha to assess the reliability of the set of scale or the test items used for the analysis. Based on the study findings, it is indisputable that the green city concept in Africa and Ghana is nascent. Nonetheless, it was apparent that the green city concept is enormously beneficial to the development of a growing African and Ghanaian economy in terms of planned new settlement, enhancing the natural environment, offering high-quality affordable housing and locally accessible work in beautiful, healthy and sociable communities. In the light of current technological developments, policy making should focus on innovations or new approaches that are environmentally friendly, socially inclusive and create value for money towards meeting the needs of the current generation without endangering the ability of future generations to meet their own needs. Development of Green City principles that enhances air quality, improve water production and supply, improved management in sanitation, promote mixed and integrative land use, maintain the health and safety of city dwellers, reduce the demand for transportation and formalise public transport, adopt renewable and efficient energy technologies and promote well sustainable construction and green buildings should inform policy making and implementation.

Non response error regarding the primary data was a major limitation for this study. This was as a result of the novelty of the concept in the Ghanaian context. Despite, this limitation, it had no significant impact on the findings and the conclusions that would be drawn from this study. The study was focused in Ghana but not from other developing countries, however, the findings of this study does not limit the generalisability since the findings of the study could be used as a lesson to other developing countries. This study did not cover the views or the preferences of the general public (layman) on green cities. The study did not focus on smart or resilient cities the alternative development of cities currently embraced as well by 
researchers and policy makers but covers only the sustainability aspect of cities (i.e. ecofriendliness or green city). The study identified innate shortcomings that presents open opportunities for further studies to contribute empirically to knowledge. Future studies should thus explore the benefits of green cities to the economic, social and environmental development of Ghana. Future studies should broaden its geographical scope to consider more countries with a larger sample size. A qualitative study of green city development in Ghana is highly recommended to identity appendage indicators of green city development peculiar to Ghanaian cities to provide novel lessons to the global research space.

\section{Conflicts of Interests}

The authors declare no conflict of interests. The funders had no role in the design of the study; in the data collection, analysis, or interpretation of data; in the writing of the manuscript, and in the decision to publish the results.

\section{Acknowledgement}

This paper forms part of a large MSc. research project aimed at developing an Apposite Framework for Green Cities Development in Developing Countries. The authors gratefully acknowledge the Ghana Education Trust Fund (GETFund) for funding this research. The authors also appreciatively acknowledge the Department of Construction Technology and Management, KNUST for supporting this research. Special appreciations also go to the Editors and Reviewers whose constructive and invaluable comments and propositions played a pivotal role in noticeably improving the quality of the work.

\section{References}


Agyekum, K., Adinyira, E., and Ampratwum, G. (2020). Factors driving the adoption of green certification of buildings in Ghana. Smart and Sustainable Built Environment. https://doi.org/10.1108/SASBE-02-2019-0017

Altman, D. G., and Bland, J. M. (2005). Standard deviations and standard errors. Bmj, 331(7521), 903. https://doi.org/10.1136/bmj.331.7521.903

Anzagira, L. F., Badu, E., and Duah, D. (2019). Towards an uptake framework for the green building concept in Ghana: a theoretical review. Resourceedings, 2(1), 57-76. https://dx.doi.org/10.21625/resourceedings.v2i1.452

Baumgärtner, S., and Quaas, M. (2010). What is sustainability economics? Ecological Economics, 69(3), 445-450. https://doi.org/10.1016/j.ecolecon.2009.11.019

Beatley, T. (2012). Green cities of Europe: Global lessons on green urbanism. Island press.

Bernard, H. R. (2017). Research methods in anthropology: Qualitative and quantitative approaches. Rowman \& Littlefield.

Berrini, M., and Bono, L. (2007). The Urban Ecosystem Europe Report 2007. An integrated assessment of the sustainability of 32 European cities. Ambiente Italia-Research Institute.

Borkan, J. M. (2004). Mixed methods studies: a foundation for primary care research. The Annals of Family Medicine, 2(1), 4-6. https://doi.org/10.1370/afm.111

Brilhante, O., and Klaas, J. (2018). Green city concept and a method to measure green city performance over time applied to fifty cities globally: Influence of GDP, population size and energy efficiency. Sustainability, 10(6), 2031-2053. https://doi.org/10.3390/su10062031

Broto, V. C., and Bulkeley, H. (2013). A survey of urban climate change experiments in 100 cities. Global environmental change, 23(1), 92-102.

Creswell, J. W., and Creswell, J. D. (2017). Research design: Qualitative, quantitative, and mixed methods approaches. Sage publications.

Darko, A., Owusu, E. K., Chan, A. C., and Afari, M. F. (2018, April). Benefits of green building: a literature review. In Cobra Conference.

Dillman, D. A., Smyth, J. D., and Christian, L. M. (2014). Internet, phone, mail, and mixedmode surveys: the tailored design method. John Wiley \& Sons.

Economist Intelligence Unit (EIU) (2009). The Green City Index. A summary of the Green City Index research series. URL: https://www. siemens. com/entry/cc/features/greencityindex_international/all/en/pdf/gci_repo rt_summary. pdf (accessed 24/03/2016). 
Elkjaer, B., and Simpson, B. (2011). Pragmatism: A lived and living philosophy. What can it offer to contemporary organization theory? Research in the Sociology of Organizations, 32, 55-84. https://doi.org/10.1108/S0733-558X(2011)0000032005

Estevez, E., Lopes, N., and Janowski, T. (2016). Smart sustainable cities: Reconnaissance study. United Nations University and International Development Research Centre (IDRC)

European Bank for Reconstruction and Development (EBRD) (2016). Green City Program Methodology; European Bank for Reconstruction and Development: London, UK, Available online via https://www.ebrd.com/documents/technical-cooporation/greencity-action-plan-in-tirana.pdf [Accessed 31 March, 2020].

European Commission (2005). Impact Assessment Guidelines; EC Document No. SEC (2005) 791; European Commission: Brussels, Belgium

European Commission (EC). (2010). EUROPE 2020: A strategy for smart, sustainable and inclusive growth. Working paper \{COM (2010) 2020\}.

Frischenbruder, M. T. M., and Pellegrino, P. (2006). Using greenways to reclaim nature in Brazilian cities. Landscape and urban planning, 76(1-4), 67-78. https://doi.org/10.1016/j.landurbplan.2004.09.043

Global Platform for Sustainable Cities, World Bank. (2018). Urban Sustainability Framework. 1st ed. Washington, DC: World Bank.

Goldsmith, S., and Crawford, S. (2014). The responsive city: Engaging communities through data-smart governance. John Wiley \& Sons.

Government of Rwanda and Global Green Growth Institute (GGGI) (2015). National Roadmap for Green Secondary City Development. Kigali. Available online via https:/gggi.org/site/assets/uploads/2017/12/National-Roadmap-for-Green-SecondaryCity-Development.pdf [Accessed 30 March, 2020].

Hammer, S., Kamal-Chaoui, L., Robert, A. and Plouin, M. (2011). Cities and Green Growth: A Conceptual Framework. OECD Regional Development Working Papers. 8/2011. Paris: OECD. http://dl.ueb.vnu.edu.vn/handle/1247/11925

Hoornweg, D., and Freire, M. (2013). Building sustainability in an urbanizing world: A partnership report. Urban Development Series Knowledge Papers; No. 17. World Bank, Washington, DC. (c) World Bank. https://openknowledge.worldbank.org/handle/10986/18665 License: CC BY 3.0 IGO."; 2013.

Hoornweg, D., Sugar, L., and Trejos Gómez, C. L. (2011). Cities and greenhouse gas emissions: moving forward. Environment and Urbanization, 23(1), 207-227. https://doi.org/10.1177\%2F0956247810392270 
Joas, M., Theobald, K., McGuinness, D., Garzillo, C., and Kuhn, S. (Eds.). (2013). Informed cities: Making research work for local sustainability. Routledge.

Kissi, E., Adjei-Kumi, T., Twum-Ampofo, S., and Debrah, C. (2020). Identifying the latent shortcomings in achieving value for money within the Ghanaian construction industry. Journal of Public Procurement. https://doi.org/10.1108/JOPP-11-2019-0075

Kline, R.B. (2015). Principles and practice of structural equation modelling. Guilford Publications.

Larbi, M. (2019). Green Urbanism in Contemporary Cities: A Socio-technical Transition Analysis (Doctoral dissertation).

Lehmann, S. (2010). Green urbanism: Formulating a series of holistic principles. SAPI EN. S. Surveys and Perspectives Integrating Environment and Society, (3.2).

Lewis, E. (2015). Green City Development Tool Kit. Asian Development Bank.

Mathers, N., Fox, N., and Hunn, A. (2007). Surveys and Questionnaires. The NIHR RDS for the East Midlands/Yorkshire \& the Humber.

McKenzie, S. (2004). Social sustainability: towards some definitions. Hawke Research Institute, University of South Australia Magill.

Mersal, A. (2017). Eco city Challenge and opportunities in transferring a city in to green city. Procedia Environmental 22-33. https://doi.org/10.1016/j.proenv.2017.03.010

Mosly, I. (2015). Barriers to the diffusion and adoption of green buildings in Saudi Arabia. Journal of Management \& Sustainability, 5(4), 104. https://doi.org/10.5539/jms.v5n4p104

Neville, C. (2007). Effective learning service: Introduction to research and research methods. UK: Bradford University School of Management.

Noy, C. (2008). Sampling knowledge: The hermeneutics of snowball sampling in qualitative research. International Journal of social research methodology, 11(4), 327-344. https://doi.org/10.1080/13645570701401305

Owusu-Manu, D.G., Debrah, C., Antwi-Afari, P., and Edwards, D.J. (2019, July). Barriers of Project Bond Initiatives in Infrastructure Financing in Ghana. In Construction Industry Development Board Postgraduate Research Conference, Springer, Cham, 1221 https://doi.org/10.1007/978-3-030-26528-1_2

Owusu-Manu, D. G., Edwards, D. J., Kukah, A. S., Parn, E. A., El-Gohary, H., and Hosseini, M. R. (2018). An empirical examination of moral hazards and adverse selection on PPP projects. Journal of Engineering, Design and Technology. https://doi.org/10.1108/JEDT-01-2018-0001 
Oyebanji, A. O., Liyanage, C., and Akintoye, A. (2017). Critical Success Factors (CSFs) for achieving sustainable social housing (SSH). International journal of sustainable built environment, 6(1), 216-227. https://doi.org/10.1016/j.ijsbe.2017.03.006

Pace, R., Churkina, G., Rivera, M., and Grote, R. (2016, December). How green is a "Green City"? A review of existing indicators and approaches, IASS Working Paper, 1-27 https://doi.org/10.2312/iass.2016.035

Polit, D. F., and Beck, C. T. (2004). Nursing research: Principles and methods. Lippincott Williams \& Wilkins.

Rooshdi, R. R. R. M., Majid, M. Z. A., Sahamir, S. R., and Ismail, N. A. A. (2018). Relative importance index of sustainable design and construction activities criteria for green highway. Chemical Engineering Transactions, 63, 151-156. https://doi.org/10.3303/CET1863026

Rosenzweig, C., Solecki, W. D., Romero-Lankao, P., Mehrotra, S., Dhakal, S., and Ibrahim, S. A. (Eds.). (2018). Climate change and cities: Second assessment report of the urban climate change research network. Cambridge University Press.

Ross, A., and Willson, V. L. (2017). One-sample T-test. In Basic and Advanced Statistical Tests, 9-12. Brill Sense.

Singh, C. S. (2018). Green construction: analysis on green and sustainable building techniques. Civil Engineering Research Journal, 4(3), 555638.

Stoddart, H. (Ed.). (2011). A Pocket guide to sustainable development governance. Stakeholder Forum.

Swanwick, C., Dunnett, N., and Woolley, H. (2003). Nature, role and value of green space in towns and cities: An overview. Built Environment (1978-), 94-106. https://www.jstor.org/stable/23288809

Tavakol, M., and Dennick, R. (2011). Making sense of Cronbach's alpha. International journal of medical education, 2, 53-55. https://dx.doi.org/10.5116\%2Fijme.4dfb.8dfd

UN-Habitat (2015). Habitat III Issue Papers on Urban and Spatial Planning and Design. UN Habitat: New York, NY, USA.

United Nations (UN) (2014). World urbanization prospects: the 2014 revision, Highlights (ST/ESA/SER. A/352). New York, United, 32.

United Nations Educational, Scientific and Cultural Organization (UNESCO) (2016). Culture Urban Future: Global Report on Culture for Sustainable Urban Development. Massgraficc \& Dhita.

World Commission on Environment and Development (1987). Our common future-The Brundtland report. Report of the World Commission on Environment and Development. 
World Economic Forum (WEF) (2016). Inspiring Future Cities \& Urban Services Shaping the Future of Urban Development \& Services Initiative. https://www.weforum.org/reports/inspiring-future-cities-urban-services-shaping-thefuture-of-urban-development-services-initiative; 2016 [accessed 1 June, 2020].

Yigitcanlar, T., and Kamruzzaman, M. (2019). Planning, Development and Management of Sustainable Cities. MDPI Books.

Zikmund, W. (2000), Exploring Marketing Research, London: Dryden Press.

\section{AUTHORS' BIOGRAPHY}

Prof. De-Graft Owusu-Manu is an Associate Professor of the Department of Construction Technology and Management of the Kwame Nkrumah University of Science and Technology. He earned his BSc. degree in Building Technology (First Class Honours) from Kwame Nkrumah University of Science and Technology. After serving as a facilitator or Teaching assistant for one year, Prof. Owusu-Manu, was enrolled by the department to pursue his PhD in Equipment Investment Finance Strategy for Large Construction Firms in Ghana. His unrivalled research expertise and stochastic research approaches have influenced and meliorated his ability to get so much of his works published in high ranked journals and peer-reviewed conferences. Prof. Owusu-Manu is the president of Green Communities International and editor for Journal of Built Environment. His research interests lies broadly in the fields of Construction Financing, Sustainable Development, Construction Economics, Project Finance Strategy (PFS), Public-Private Partnerships (PPP), Private Finance Initiatives (PFI), Project Management, Procurement Management, Construction Education \& Curriculum Development, Investment Appraisals \& Development Economics, Managerial Economics, Financial Management, Construction Economies, Risk Management, Construction Commerce and Business Management, Corporate Strategy, Organizational Learning and Change, Infrastructure Financing, Plant \& Equipment Management Science.

Mr. Caleb Debrah is a graduate assistant at the Department of Construction Technology and Management at the Kwame Nkrumah University of Science and Technology, Ghana. Mr. Debrah obtained his bachelor's degree (Hons) in Construction Technology and Management from Kwame Nkrumah University of Science and Technology with First Class Honours. Caleb was the former president for the Building Technology Students Society and College of Art and Built Environment Students Association where he received the best student Leader 
Award in the 2017/18 academic year in the same university. He is currently a post graduate student of Construction Management in the same department having received a scholarship award from the Ghana Educational Trust Fund (GETFund). Mr. Debrah is an astute research assistant who combines nonpareil research skills to leadership roles. His research interest encapsulates project bonds financing, sustainability and sustainable development, green bonds, and construction innovation, construction innovation, robotics and sensing technologies. He is an incorporate member of Ghana Institute of Construction and a probationer of the Ghana Institution of Surveyors.

Dr. Eric Oduro-Ofori is a Senior Lecturer in Regional Development Planning at the Department of Planning, Kwame Nkrumah University of Science and Technology, Kumasi and a Management Training Consultant. He holds a PhD in Local Economic Development Planning and Local Governance. He is an experienced and results driven lecturer, researcher and training expert in strategic planning and management, local economic development, entrepreneurship and livelihood development, local governance, and local government finance. His skills cover strategic planning, local economic development analysis; spatial competitive development analysis; spatial development techniques; Livelihood Analysis; Application of the Logical Framework, Results Based Management Framework; SWOT; POCC; PESTLE; Fishbone Analysis; Needs Assessment Techniques; Institutional Assessment and Management; Poverty Mapping; Accessibility Analysis; Application of Participatory Techniques; Research and Project Proposal Development; Projects Conception and Design; Training and Facilitation; Development Plan Preparation; Report Writing; Research Data Management and Analysis; Results Based Monitoring and Evaluation techniques among others. His interest in helping train young people to acquire skills for life as well promote institutional and local level development.

Professor David J. Edwards BSc (Hons), PhD, FIoQ is a Professor of Plant \& Machinery Management \& Visiting Professor at the Faculty of Engineering and the Built Environment, University of Johannesburg, South Africa. His work has been funded through engineering councils, government bodies (eg. HSE, Highways England, UK Home Office and Defence Logistic Organisation, UK Ministry of Defence) \& an extensive network of industrial collaborations. He has published over 300 scientific research papers in leading international journals \& numerous conference contributions \& textbooks. He is a peer referee for over 50 scientific journals. Amongst his many awards \& accolades, two are held most dearly, 
Recipient of the Commander's Coin, US Department of Defence (2011) for his work into hand-arm vibration \& Chief for Education Development, Ashanti Region, Ghana.

Mr. Prince Antwi-Afari is a PhD. Student at the University of Hong Kong, Pokfulam, Hong Kong SAR, China having won a Hong Kong PhD Fellowship Scheme award. Prince was formerly a graduate research, and teaching assistant at the Department of Construction Technology and Management at the Kwame Nkrumah University of Science and Technology, Ghana. Mr. Antwi-Afari holds a Bachelor of Science degree (Hons) in Construction Technology and Management from the Kwame Nkrumah University of Science and Technology where he completed with First Class Honours toping his entire graduating class. He also holds an MSc (Hons) degree in Construction Management from the same university. His research interests and experiences broadly lie within construction innovation, smart construction, smart construction objects, smart construction materials, construction informatics, and sustainability and construction waste management. Mr. Antwi-Afari is also an incorporate member of the Ghana Institute of Construction and a probationer of the Ghana Institution of Surveyors. 